\title{
IDENTIFIKASI JENIS DAN ARAH SESAR AKTIF DI WILAYAH SULAWESI SELATAN MENGGUNAKAN METODE HIPOCENTER DAN CENTROID (H-C)
}

\author{
Lorna, Rahmaniah, dan Ayusari Wahyuni ${ }^{1}$ \\ 1Jurusan Fisika, Fakultas Sains Dan Teknologi, UIN Alauddin Makassar \\ Email: lornarlansyah.96@gmail.com,nia.physics08.uin@gmail.com, \\ ayusari_wahyuni@uin-alauddin.ac.id
}

\begin{abstract}
This study aims to identify the direction and type of active faults in the region of South Sulawesi by using the hypocenter and Centroid $(\mathrm{HC})$. The data used is secondary data obtained from the hypocenter USGS, IRIS, GEOFON website and the data obtained from BMKG centroid that is processed using the focus mechanism to coordinate limit $-3^{\circ}-6^{\circ} 30^{\prime}$ LS $-119^{\circ}-120^{\circ}$ BT. According to the research by the method of $\mathrm{HC}$ obtained by the type and direction of the active faults in the region I with the type of normal foult directed N6E/32 south-north, region II with the type of strike-slip fault directed N358E/83 north-south, Region III with the type of oblique fault directed N74E/16 southwest-northeast, Region IV with the type of normal foult directed N109E/56 northwest- southeast and in the region of $V$ with the type of strike-slip fault directed N332E/50 southeast-northwest.
\end{abstract}

Keywords: Centroid, Focus Mechanism, HC methods, the hypocenter, Walanae Fault

\section{PENDAHULUAN}

\section{Latar Belakang}

Indonesia merupakan daerah dengan manifestasi tektonik yang ditimbulkan berupa sesar dan gunung api teraktif di Dunia (Kaharuddin, 2011) karena terletak pada pertemuan antara tiga lempeng yang aktif bergerak (triple junction) yaitu Lempeng Pasifik yang bergerak relatif ke arah Barat dengan kecepatan $12 \mathrm{~cm}$ per tahun. Lempeng Indo-Australia yang bergerak relatif ke arah Utara dengan kecepatan $7 \mathrm{~cm}$ per tahun dan menyusup ke dalam Lempeng Eurasia yang relatif diam sehingga menyebabkan Pulau Sulawesi memiliki kondisi geologi yang kompleks dan rumit. Pergerakan dari lempeng-lempeng yang berbeda jenis tersebut menciptakan jalur penunjaman dan jalur subduksi yang terus aktif hingga sekarang sehingga pergerakan dari lempeng tersebut merupakan generator utama aktivitas gempabumi yang menimbulkan terjadinya sesar atau sesar regional dan lokal daerah.

Struktur geologi di Sulawesi didominasi oleh sesar mendatar sinistral dan sesar naik dengan arah barat laut - tenggara (Hamilton, 1979). Sesar-sesar aktif yang berada di Sulawesi yaitu sesar Gorontalo, sesar Palu-Koro (dari Flores, Palu hingga Selat Makassar), sesar Matano, sesar Lawanopo (Sulawesi Tenggara) dan 
Sesar Walanae (Sulawesi Selatan). Keberadaan sesar-sesar aktif ini menyebabkan Sulawesi rawan terhadap bencana terutama masalah gempa dan tsunami. Menurut Atika Kurniati (2017) dalam penelitiannya gempa bumi yang terjadi di Sulawesi Selatan merupakan jenis gempa dangkal, gempa menengah, dan gempa dalam yang terjadi di darat dan di laut. Secara regional, pulau Sulawesi mendapat tekanan dari luar sehingga terjadi deformasi secara terus menerus, seperti tekanan dari Laut Flores di bagian selatan mengaktifkan sesar Palu-Koro dan Walanae. Menurut Kaharuddin (2011) berdasarkan pengembangan tektonik, Sesar Walanae, Palu-koro, Matano termaksud sesar transcurrent yang bersifat sinitral dan sesar gorontalo yang bersifat destral. Hal ini mengakibatkan seringnya terjadi gempabumi tektonik di daerah yang saling berlawanan sehingga menimbulkan retakan yang terjadi di kulit bumi. Berdasarkan penelitian Madlazim (2017) gerakan batuan ini bisa begitu cepat sehingga perlu dilakukan identifikasi arah pergerakan bidang sesar dengan kekuatan di atas 3 SR dengan menggunakan metode $\mathrm{H}-\mathrm{C}$ untuk mengetahui jenis sesar yang menyebabkan gempabumi. Metode $\mathrm{H}-\mathrm{C}$ lebih unggul dari metode sebelumnya yaitu metode inversi karena tidak memerlukan banyak stasiun seismik. Penentuan jenis dan arah sesar ini dapat memberikan informasi kepada masyarakat yang berada di wilayah sesar tersebut sebagai bahan pertimbangan dalam melakukan pembangunan. Untuk menentukan jenis dan arah sesar yang menyebabkan gempabumi parameter yang digunakan yaitu hiposenter, centroid dari kejadian gempabumi. Hiposenter kejadian gempabumi ini bersumber dari jaringan seismik BMKG, IRIS, USGS dan GEOFON. Dimana jarak hiposenter terhadap salah satu bidang nodal dari dua bidang yang paling mendekati $0 \mathrm{~km}$ merupakan bidang sesar teraktifkan. Berdasarkan latar belakang tersebut, penulis akan melakukan penelitian dengan judul "Identifikasi Jenis dan Arah Sesar Aktif di Wilayah Sulawesi Selatan Menggunakan Metode Hiposenter dan Centroid (H-C)".

\section{Tujuan Penelitian}

Tujuan pada penelitian ini adalah untuk mengetahui jenis dan arah sesar aktif di wilayah Sulawesi Selatan menggunakan metode Hiposenter dan Centroid ( $\mathrm{H}-\mathrm{C})$.

\section{METODE PENELITIAN}

\section{Waktu dan Lokasi Penelitian}

Waktu penelitian ini pada bulan Februari sampai Juni 2018 dan lokasi yang menjadi objek penelitian adalah wilayah Sulawesi Selatan pada koordinat $3^{\circ}-6^{\circ} 30^{\prime}$ LS dan $119^{\circ}-120^{\circ} \mathrm{BT}$.

\section{Alat dan Bahan}

Alat dan bahan yang digunakan pada penelitian ini adalah

1. Software ; Notepad, ArGIS 10.3, Seisgram2K, AZMTAK, Matlab R2017a.

2. Data yang digunakan yaitu data event gempa berupa data wavefrom, waktu kejadian gempa, longitude, latitude, depth, magnitudo dan centroid pada periode 2008-2017. 


\section{Pengambilan Data}

Data yang digunakan adalah data centroid dari event gempa yang terjadi di Wilayah Sulawesi Selatan periode 2008-2017. Data ini berisi informasi koordinat gempa, magnitude, kedalaman (depth) dan data wavefrom, dengan magnitude $\geq 3$ SR. Data tersebut diperoleh dari website BMKG (repogempa.bmkg.go.id) yang menyediakan data gempa lokal. Menggunakan data hiposenter yang diperoleh dari website USGS (www.earthquake.usgs.gov/earthquakes), dan dari website IRIS (http://ds.iris.edu/wilber3/findevent) serta data hiposenter dari website GEOFON (http://202.90.198.100/webdc3/) sebagai data pembanding.

\section{Pengolahan Data}

a. Membuat peta seismisitas gempa

1. Menginput data event gempa berupa data koordinat, magnitudo, dan kedalaman ke dalam progam Ms. Excel.

2. Membuat tabel frekuensi yang terdiri dari tabel periode terjadinya gempabumi dengan kriteria magnitudo $\geq 3$ SR yang digunakan untuk melihat aktivitas gempa bumi yang terjadi setiap tahun pada wilayah Sulawesi Selatan.

3. Mengeplot data dari program Excel ke dalam software ArGIS 10.3 dengan membagi data berdasarkan kedalaman hiposenternya untuk mengetahui sebaran gempabumi di Wilayah Sulawesi Selatan periode 2008-2017.

b. Menentukan jenis sesar dan data centroid

1. Menginput data waveform (data dalam bentuk gelombang) ke dalam software Seisgram2K.

2. Melakukan picking pada Data gelombang tersebut sehingga diperoleh data gelombang $P$ dengan spesifikasi:

e : Gelombangnya jelas

i : Tidak jelas

c : Gelombang kompresi (gelombang naik)

d : Gelombang dilatasi (gelombang turun)

3. Menginput data hasil picking gelombang $P$, gelombang turun/dilatasi (-) dan gelombang naik/kompresi $(+)$ (output dari software Seisgram2K) dan data latitude, longitude, depth, jumlah stasiun pencatat gempa, dan kode stasiun kemudian dijadikan input dalam software AZMTAK dalam bentuk Notepad.

4. Menginput data ke dalam program Notepad dengan data lain berupa data koordinat waktu dan lokasi kejadian, kedalaman, magnitude, jumlah yang digunakan, waktu bacaan gelombang $P$ dan koordinat lokasi setiap stasiun pencatat gempabumi.

5. Hasil yang menjadi output dari software AZMTAK berupa bola focal dan nilai stike (jurus sesar), dip (sudut kemiringan), dan rake (besar sudut pergeseran) untuk setiap titik gempabumi atau data Centroid.

6. Menganalisis pola untuk menegetahui jenis sesar yang terbentuk berdasarkan literature yang ada. 
c. Menentukan arah dan sesar aktif berdasarkan metode $\mathrm{H}-\mathrm{C}$

1. Data yang digunakan adalah data centroid berupa nilai strike, dip dan rike. Dan data hiposenter untuk setiap jaringan seismik yaitu GEOFON, IRIS dan USGS berupa data longitude, latitude, dan depth.

2. Mengeplot data ke dalam Matlab R2017a untuk mengetahui sesar tersebut termaksud sesar yang aktif berdasarkan titik acuan berupa data hiposenter serta arah sesar tersebut.

\section{HASIL DAN PEMBAHASAN}

\section{Frekuensi Gempa Sulawesi Selatan periode 2008-2017}

Data event gempabumi Sulawesi Selatan periode 2008-2017 yang diperoleh dari BMKG memiliki informasi mengenai longitude, latitude, waktu kejadian, depth, dan magnitudo untuk setiap tahun dan dikelompokkan berdasarkan data dan grafik seperti berikut:

Tabel 1. Data frekuensi gempa periode 2008-2017

\begin{tabular}{|c|c|c|}
\hline No. & Tahun & $\begin{array}{c}\text { Jumlah } \\
\text { kejadian } \\
\text { gempa }\end{array}$ \\
\hline 1 & 2008 & 5 \\
\hline 2 & 2009 & 11 \\
\hline 3 & 2010 & 24 \\
\hline 4 & 2011 & 12 \\
\hline 5 & 2012 & 16 \\
\hline 6 & 2013 & 23 \\
\hline 7 & 2014 & 13 \\
\hline 8 & 2015 & 26 \\
\hline 9 & 2016 & 20 \\
\hline 10 & 2017 & 12 \\
\hline \multicolumn{2}{|c|}{ Jumlah } & 162 \\
\hline
\end{tabular}




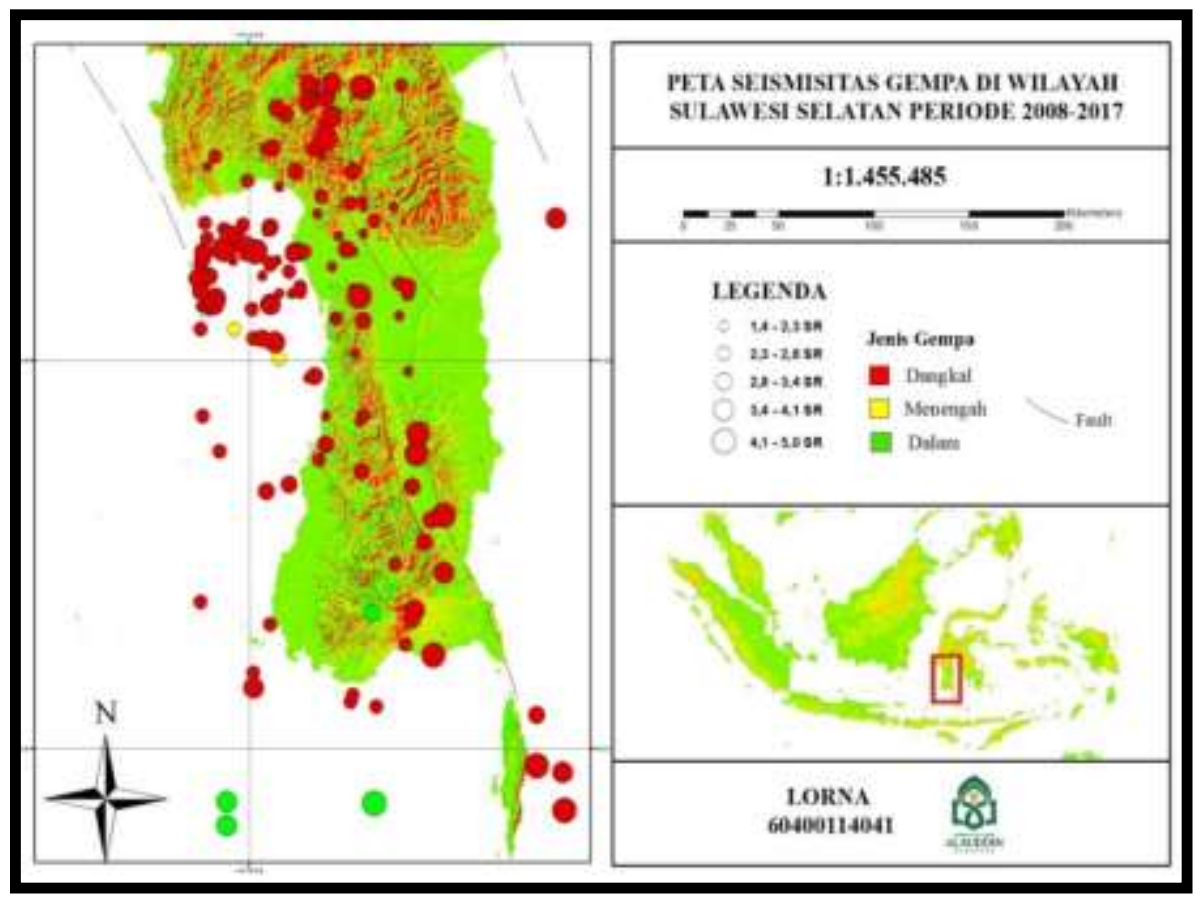

Gambar 1. Peta seismisitas gempa bumi Sulawesi Selatan periode 2008-2017

Data magnitudo dan kedalaman (depth) gempabumi untuk wilayah Sulawesi Bagian Selatan periode 2008-2017 dibatasi pada koordinat $3^{\circ}-6^{\circ} 30^{\prime} \mathrm{LS}$ dan $119^{\circ}$ $120^{\circ} \mathrm{BT}$ diperoleh hasil plot data gempabumi berupa data harian gempabumi pada kurun waktu 10 tahun dengan menggunakan software ArcGis 10.3. Magnitudo yang digunakan pada peta seismisitas merupi kan gempabumi dengan magnitudo 1-5 SR. C empabumi yang sering terjadi terg long gempabumi kecil. Pada gambar 1 $\mathrm{b}$ srdasarkan kedalaman dan magnitudi memperlihatkan bahwa gempabumi yang terjadi bersumber dari gempabumi di darat maupun di laut. Peta seismisitas juga memperlihatkan bahwa aktivitas kegempaan yang terjadi cukup tinggi dengan titik hiposenter yang relatif dangkal. Sebaran gempabumi yang terjadi di darat dan di laut pada peta seismisitas berdasarkan kedalamannya merupakan gempabumi dangkal, menengah dan dalam. Di darat kedalaman terbesar yaitu $610 \mathrm{Km}$ dan terendah 2 $\mathrm{Km}$ sedangkan di laut kedalaman terbesar yaitu $510 \mathrm{Km}$ dan yang terendah $10 \mathrm{Km}$. Berdasarkan kekuatan gempanya, gempabumi yang terjadi di darat dan di laut merupakan gempa mikro ( $>1 \mathrm{SR}$ ) yarg tidak dirasakan sampai dengan gempa sedang ( $\leq 5 \mathrm{SR}$ ) yang bisa saja dapat musak.

\section{Identifikasi Jenis Sesar Di Wilayah Su.awesi Selatan Periode 2008-2017}

1. Pengolahan data gempabumi dengan menggunakan Software Seisgram2K

Berdasarkan pengolahan data gempabumi (lampiran L.3) menggunakan software Seisgram2K maka diperoleh hasil berupa pola gelombang $\mathrm{P}$. 


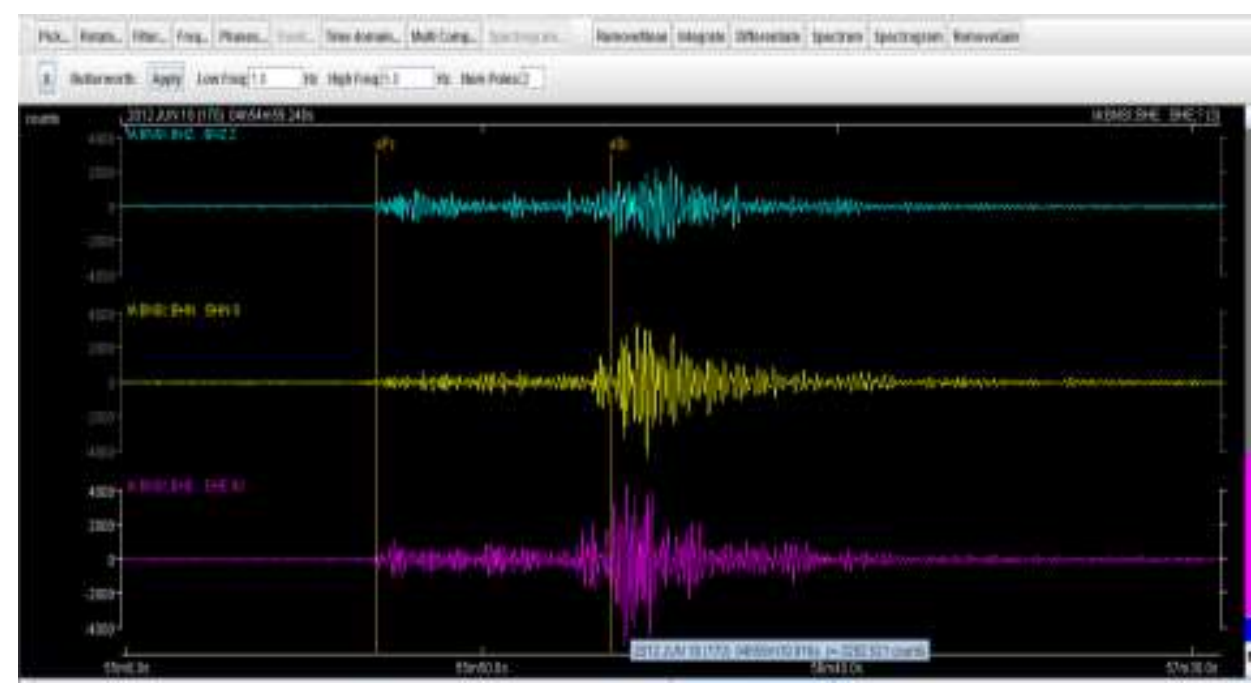

Gambar 2. Salah satu hasil picking gelombang P pada stasiun BNSI dengan menggunakan software Seisgram2K

Hasil picking data gelombang dari setiap stasiun gempa pada software Seisgram2K akan menghasilkan pola gelombang untuk setiap stasiun berupa gelombang dilatasi atau pola gelombang turun (D) dan pola gelombang kompresi atau gelombang naik $(C)$ yang disajikan dalam bentuk file Notepad. Terdapat tiga komponen sensor data yaitu BHZ (pola gelombang berwarna biru), BHE (pola gelombang berwarna ungu), dan BHN (pola gelombang berwarna kuning). Waktu tiba gelombang $\mathrm{P}(\mathrm{tP})$ diperoleh dari hasil picking pada komponen $\mathrm{BHZ}$ atau vertikal gelombang sementara untuk waktu tiba gelombang $S$ diperoleh dari hasil picking pada komponen BHN dan BHE. Berikut adalah salah satu output hasil pengolahan dan penelitian dari software Seisgram2K.

Tabel 2. salah satu output dari Software Seigram $2 \mathrm{~K}$

\begin{tabular}{|c|c|c|c|}
\hline $\begin{array}{c}\text { Nama } \\
\text { Stasiun }\end{array}$ & $\begin{array}{c}\text { Jenis } \\
\text { Gelombang }\end{array}$ & $\begin{array}{c}\text { Pola } \\
\text { Gelombang }\end{array}$ & tP \\
\hline BKSI & $\mathrm{P}$ & $\mathrm{D}$ & 34.016 \\
\hline KAPI & $\mathrm{P}$ & $\mathrm{C}$ & 39.345 \\
\hline BSSI & $\mathrm{P}$ & $\mathrm{C}$ & 48.456 \\
\hline SPSI & $\mathrm{P}$ & $\mathrm{C}$ & 56.751 \\
\hline $\mathrm{KKSI}$ & $\mathrm{P}$ & $\mathrm{C}$ & 10.619 \\
\hline TTSI & $\mathrm{P}$ & $\mathrm{D}$ & 12.551 \\
\hline $\mathrm{MMSI}$ & $\mathrm{P}$ & $\mathrm{C}$ & 19.923 \\
\hline
\end{tabular}

2. Pengolahan data gempa bumi dengan menggunakan Software AZMTAK

Data yang diperoleh dari arah gerakan pertama untuk pola gelombang $P$ pada setiap stasiun berupa pola gerakan kompresi dan pola gerakan dilatasi. Dari program Notepad tersebut kemudian diolah menggunakan software AZMTAK 
dimana hasil dari software Seisgram2K yang akan menjadi input datanya. Berikut ini adalah salah satu hasil polaritas gelombang yang diperoleh dari penelitian.

Tabel 3. Format salah satu data input gempa pada software AZMTAK

\begin{tabular}{|c|c|c|c|}
\hline $\begin{array}{c}\text { Koordinat } \\
\text { Gempa }\end{array}$ & $\begin{array}{c}\text { Kedalaman } \\
\text { Gempa }\end{array}$ & Stasiun & $\mathrm{C} / \mathrm{D}$ \\
\hline \multirow{2}{*}{$\begin{array}{c}\text { Latitude } \\
-5,38\end{array}$} & & $\mathrm{BKSI}$ & -1 \\
\cline { 3 - 4 } & \multirow{4}{*}{$\begin{array}{c}\text { Longitude } \\
120,03\end{array}$} & $\mathrm{KAPI}$ & 1 \\
\cline { 3 - 4 } & & $\mathrm{BSSI}$ & 1 \\
\cline { 3 - 4 } & & $\mathrm{SPSI}$ & 1 \\
\cline { 3 - 4 } & & $\mathrm{KKSI}$ & 1 \\
\cline { 3 - 4 } & & $\mathrm{TTSI}$ & -1 \\
\cline { 3 - 4 } & & $\mathrm{MMSI}$ & 1 \\
\hline
\end{tabular}

Data pola gelombang $P$ yang menjadi input untuk software AZMTAK berupa nilai dilatasi -1 dan nilai kompresi 1 , sementara hasil yang akan menjadi outputnya menunjukkah hasil orientasi bidang nodal berupa bola fokal, nilai strike, dip dan rake. Berikut ini merupakan salah satu output dari hasil pengolahan dan penelitian.

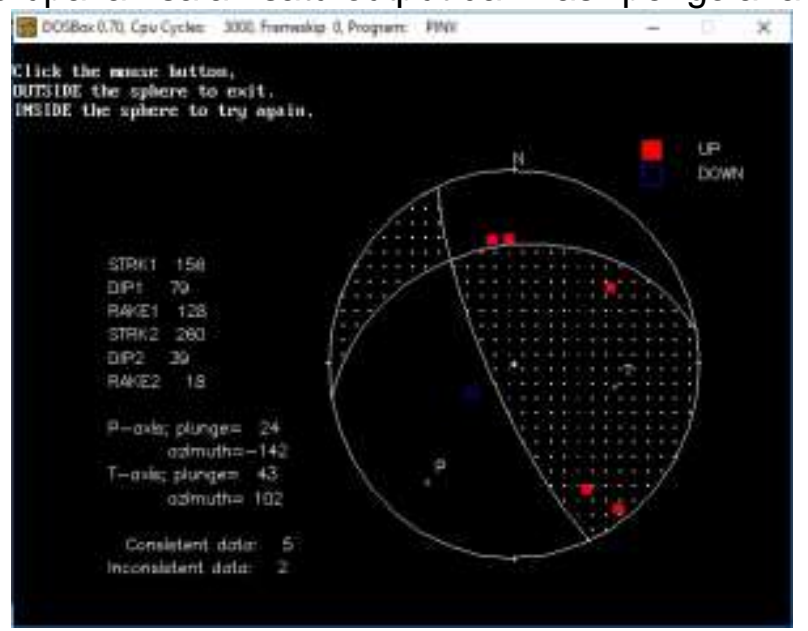

Gambar 3. Salah satu hasil pengolahan dari software AZMTAK

Berdasarkan output dari software AZMTAK distribusi data polaritas ditunjukkan oleh warna merah (up) yang merupakan kompresi dari gerak awal gelombang $P$ dan down yaitu dilatasi. Parameter sesar yang diperoleh yaitu strike, dip dan rake pada bidang nodal 1 dan bidang nodal 2. Pada gambar 4.4 juga terdapat sumbu kompresif $(\mathrm{P})$ dan sumbu tension $(\mathrm{T})$ dengan masing-masing sudut plunge dan azimuth.

Sebaran Jenis Sesar Di Wilayah Sulawesi Selatan periode 2008-2017

Mekanisme fokus digunakan untuk mengetahui jenis dan arah sesar di wilayah Sulawesi Selatan periode 2008-2017 dengan data gempa yang digunakan 
terdiri dari waktu kejadian, koordinat, kedalaman, dan magnitudo gempa. Kriteria magnitudo yang digunakan yaitu 3-5 SR dengan kedalaman 0-650 km serta batasan wilayah yang digunakan berada di sekitar Sesar Walanae. Berdasarkan gambar 4.5 dapat dilihat bahwa terdapat 24 bola fokal pada sebaran mekanisme fokus gempabumi.

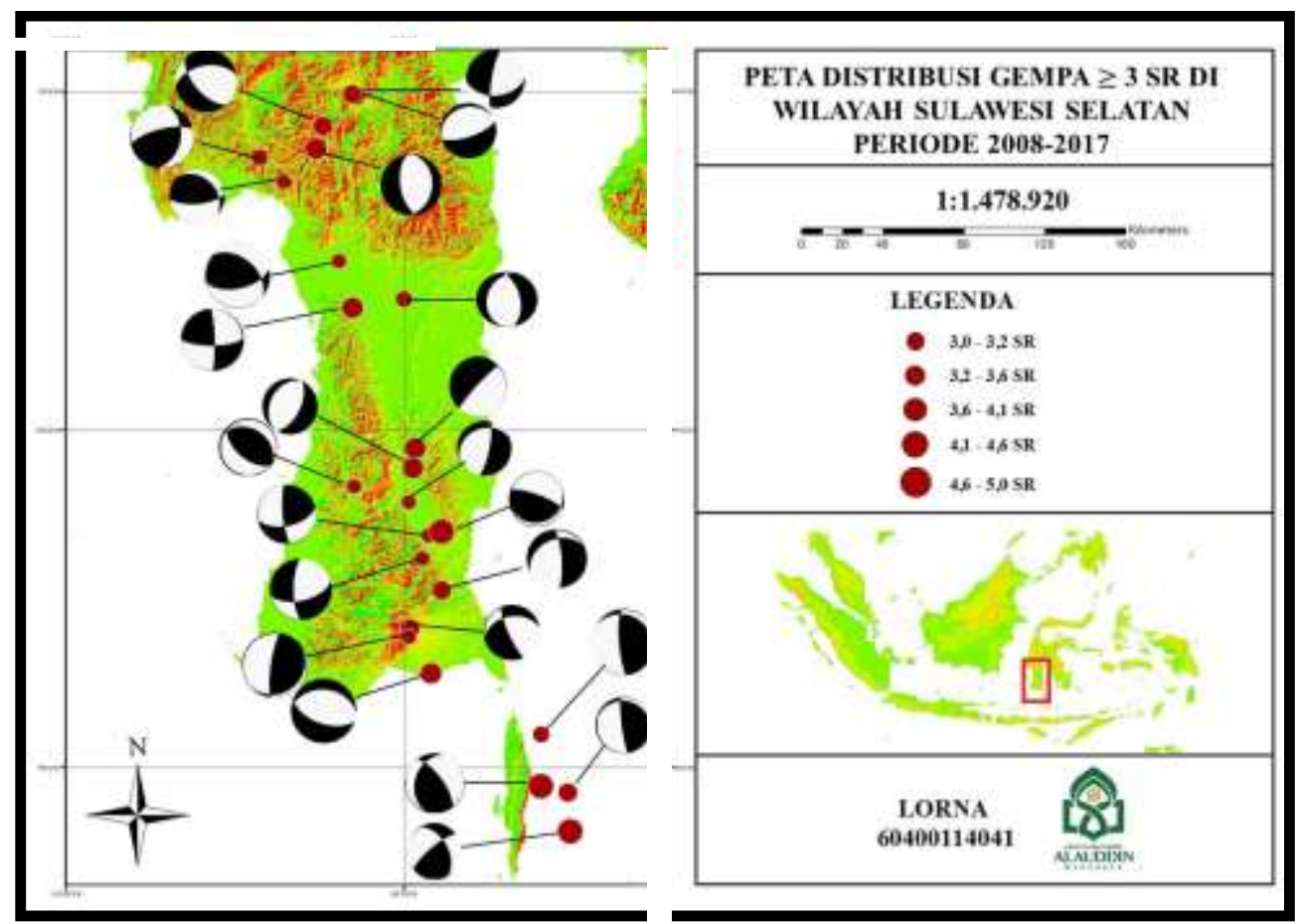

Gambar 4. Peta bola fokal mekanisme fokus gempa bumi Sulawesi Selatan periode 2008-2017.

Berdasarkan hasil analisa yang telah dilakukan maka diperoleh parameter orientasi sesar berupa nilai strike, dip, dan rake dari dua nodal planes yang dihasilkan dari program focal mechanism.

Tabel 4. Pola sesar penyebab gempa

\begin{tabular}{|c|c|c|c|}
\hline No. & Beachball & Jenis Sesar & Jumlah \\
\hline 1 & & $\begin{array}{c}\text { Sesar turun } \\
\text { (normal fault) }\end{array}$ & 6 \\
\hline 2 & & $\begin{array}{c}\text { Sesar geser } \\
\text { (strike slip) }\end{array}$ & 9 \\
\hline
\end{tabular}




\begin{tabular}{|c|c|c|}
\hline 3 & & $\begin{array}{c}\text { Sesar oblique } \\
\text { (oblique fault) }\end{array}$ \\
\hline 4 & $\begin{array}{c}\text { Sesar naik } \\
\text { (reverse fault) }\end{array}$ & 2 \\
\hline
\end{tabular}

Gambar 4 menunjukkan sesar yang terjadi di wilayah Sulawesi Selatan pada periode 2008-2017 yang secara umum didominasi oleh Sesar geser (strike slip) dan Sesar oblique (oblique fault) atau sesar kombinasi yang ditandai dengan gambar belahan bola berwarna hitam adalah kompresi dan warna putih adalah dilatasi. Jika terdapat 4 bagian dengan warna gelap terang selang seling maka itu dinamakan sesar geser dan jika terdapat 3 bagian, apabila ditengah berwarna gelap maka itu dinamakan sesar naik begitu sebaliknya, apabila ditengah berwarna terang maka itu dinamakan sesar turun serta sesar kombinasi yang sering disebut sesar oblique atau sesar geser naik/turun. Untuk memudahkan pembacaan jenis sesar, berikut ini merupakan peta fokal sebaran gempabumi di wilayah Sulawesi Selatan dimana terdapat 27 bola focal yang dibagi menjadi 5 region. Adapun region yang dimaksud sebagai berikut:

1. Jenis sesar pada region I

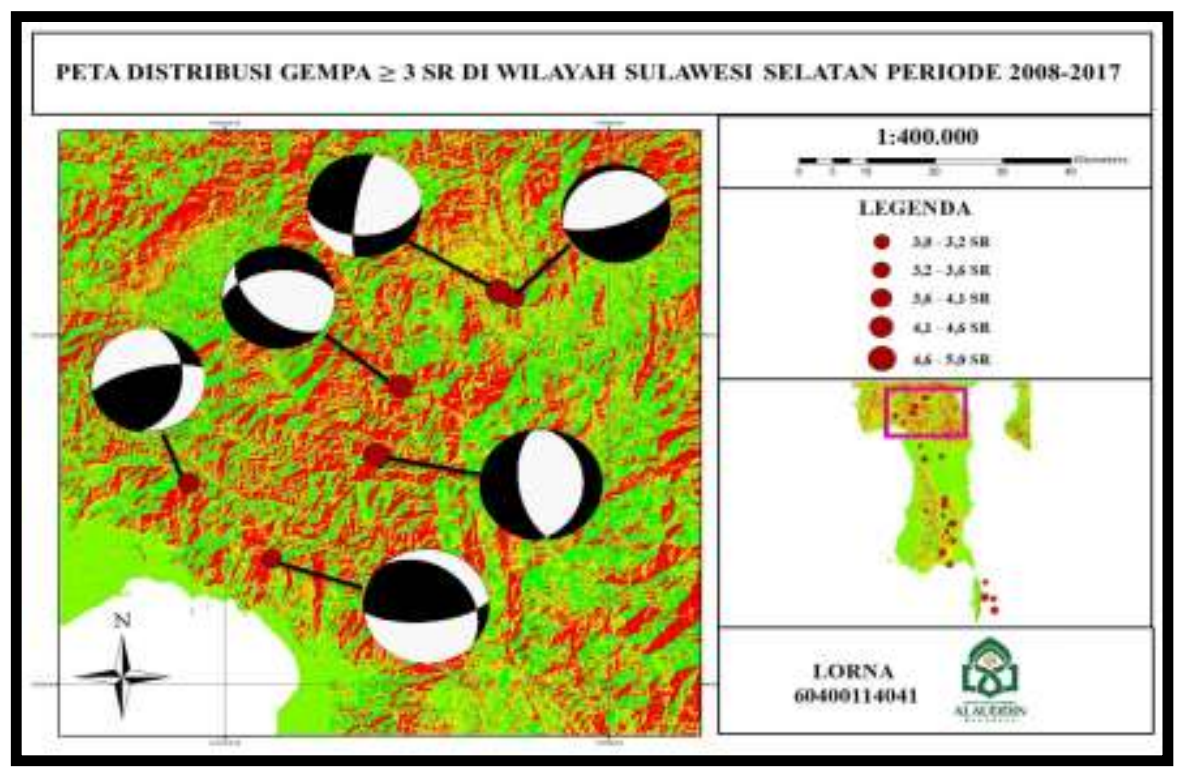

Gambar 5. Sebaran jenis sesar pada region I 
2. Jenis sesar pada region II

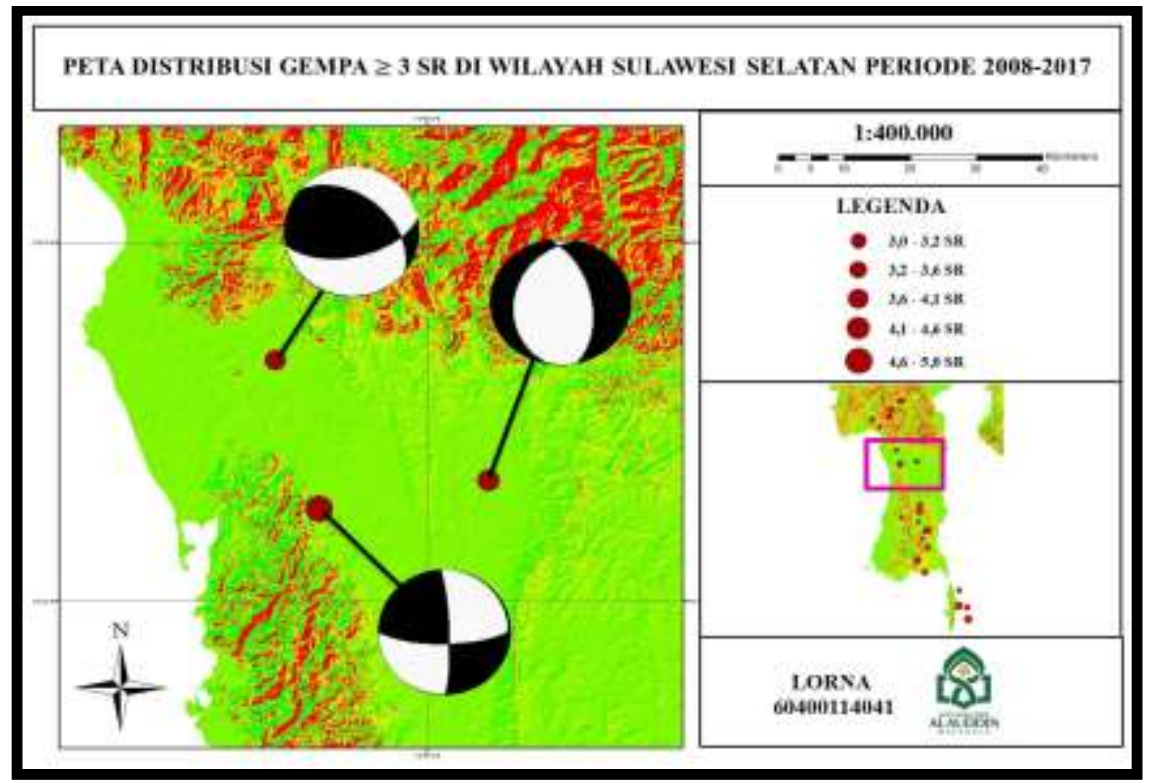

Gambar 6. Sebaran jenis sesar pada region II

3. Jenis sesar pada region III

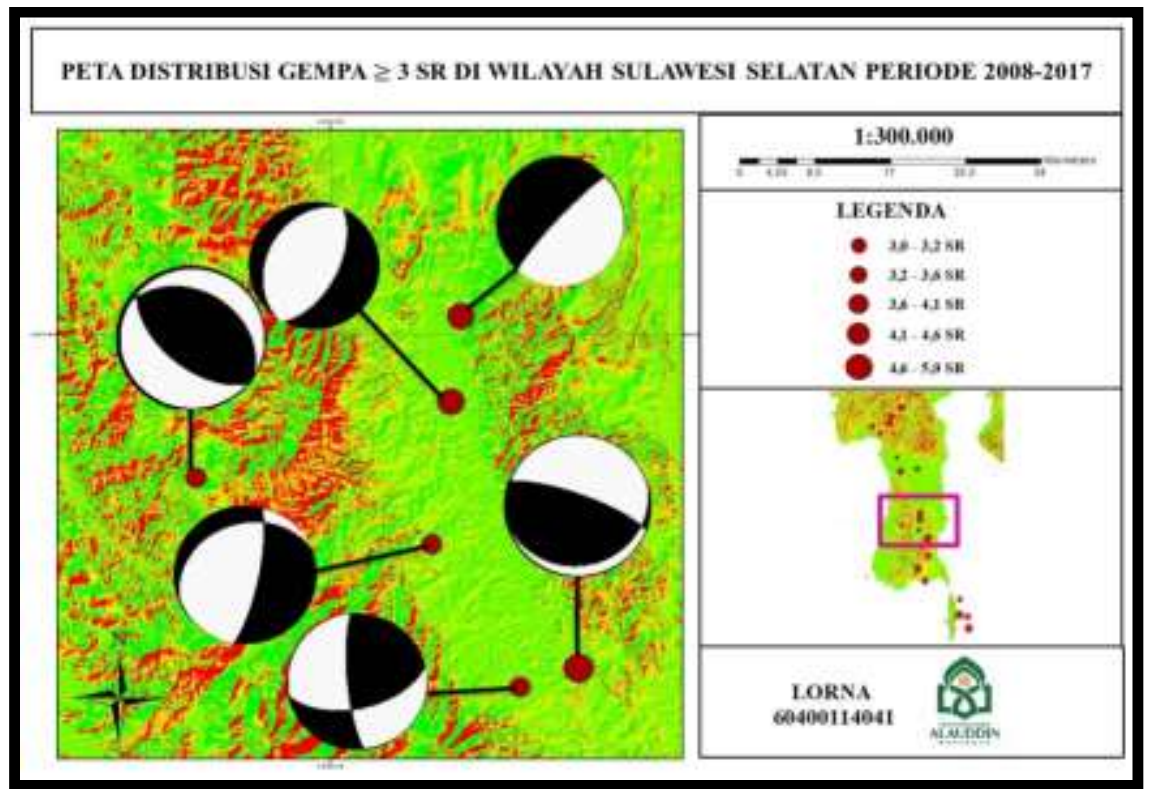

Gambar 7. Sebaran jenis sesar pada region III 
4. Jenis sesar pada region IV

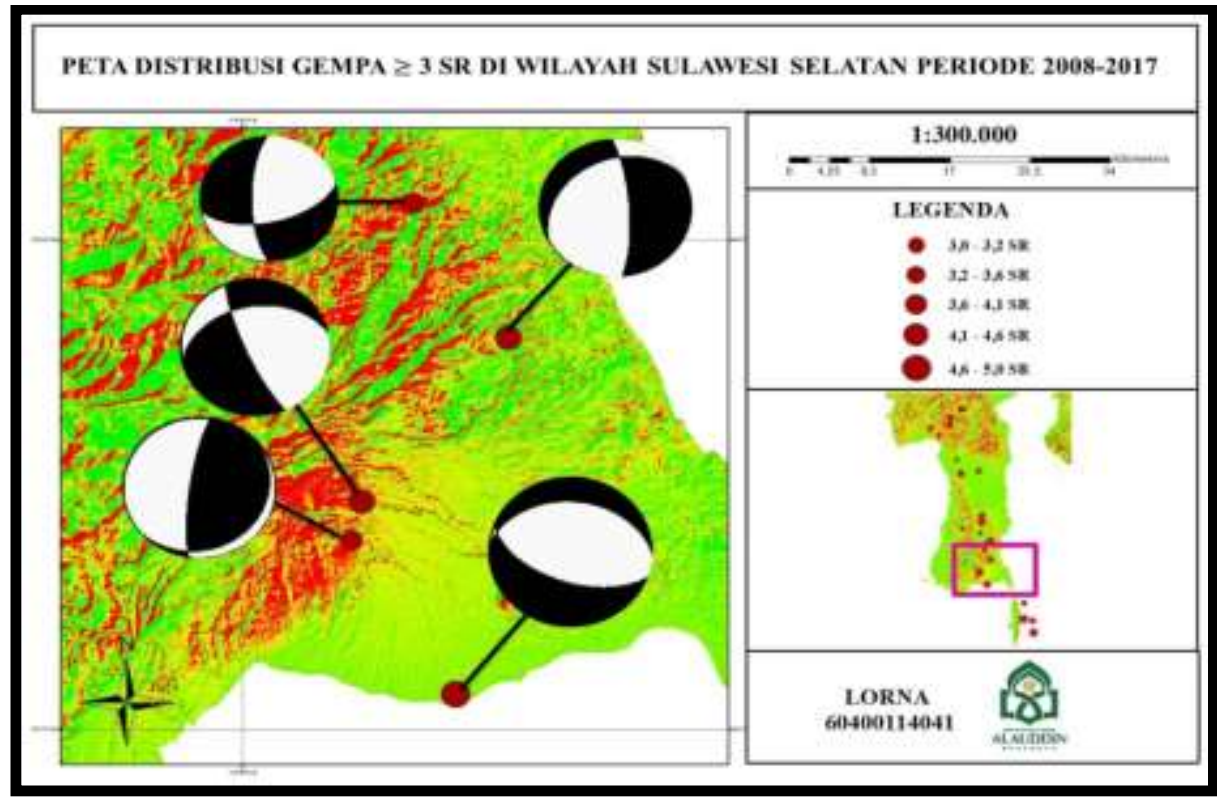

Gambar 8. Sebaran jenis sesar pada region IV

5. Jenis sesar pada region $\mathrm{V}$

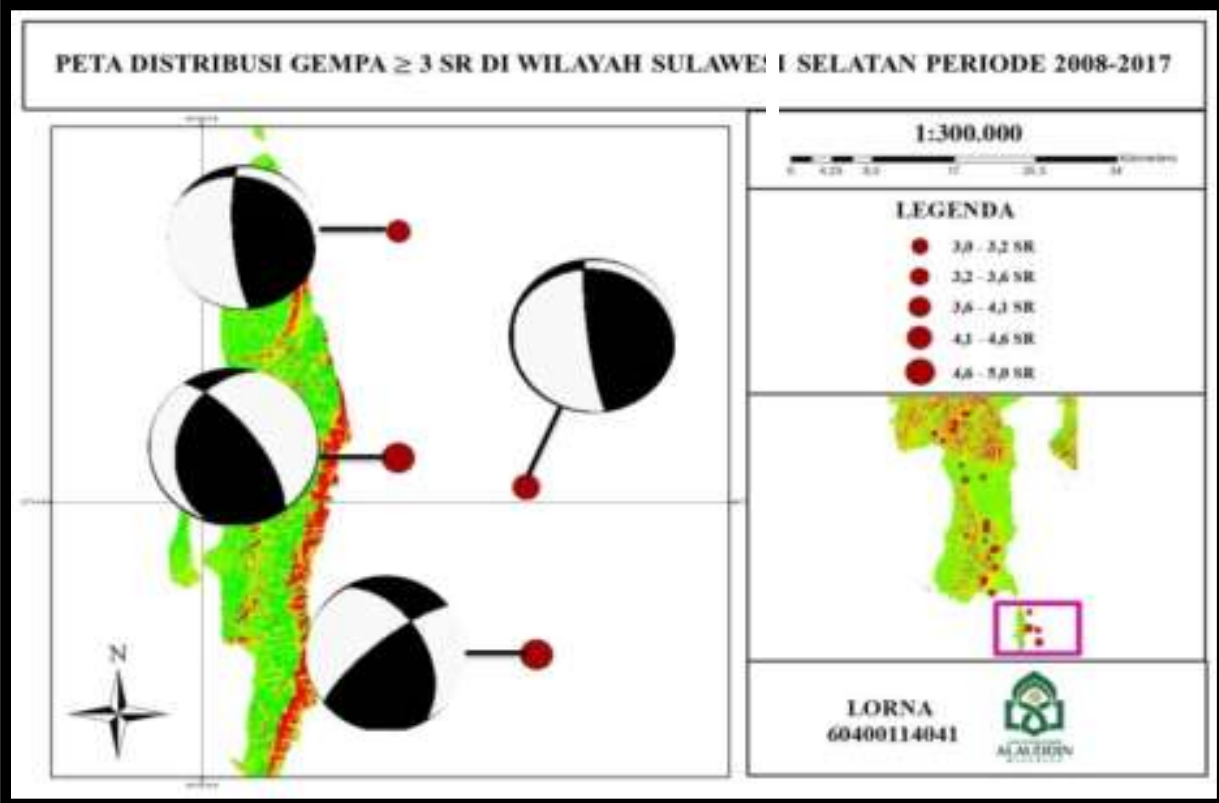

Gambar 9. Sebaran jenis sesar pada region $\mathrm{V}$ 


\section{Identifikasi Arah Sesar Berdasarkan Metode HC-plot}

Data hasil penelitian berupa bidang sesar yang teraktifkan dari beberapa gempabumi yang memiliki magnitudo 4-5 SR di wilayah Sulawesi Selatan pada periode 2008-2007. Parameter yang digunakan yaitu hiposenter dan centroid. Berikut ini hasil pengolahan data untuk setiap region dengan mengambil 1 data dari setiap region.

1. Arah sesar pada region I

Lokasi centroid berada pada lintang $-3,25^{\circ}$ LS, bujur $119,61^{\circ} \mathrm{BT}$ dan berada pada kedalaman $10 \mathrm{Km}$. lokasi hiposenter gempabumi yang berada pada lintang $3,167^{\circ} \mathrm{LS}$ dan bujur $119,779^{\circ} \mathrm{BT}$ serta berada pada kedalaman $23,7 \mathrm{Km}$.

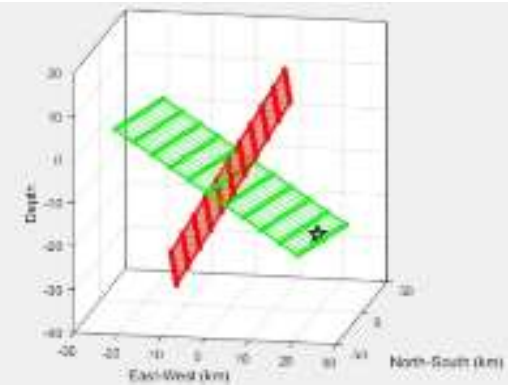

Gambar 10. Output dari program H-C Plot berupa bidang sesar region I

\section{Arah sesar pada region II}

Gempa pada region II dengan lokasi centroid berada pada lintang $-3,96^{\circ} \mathrm{LS}$, bujur $119,77^{\circ} \mathrm{BT}$ dan berada pada kedalaman $13 \mathrm{Km}$. lokasi hiposenter gempabumi yang berada pada lintang $-3,93^{\circ}$ LS dan bujur $119,75^{\circ}$ BT serta berada pada kedalaman $33 \mathrm{Km}$.

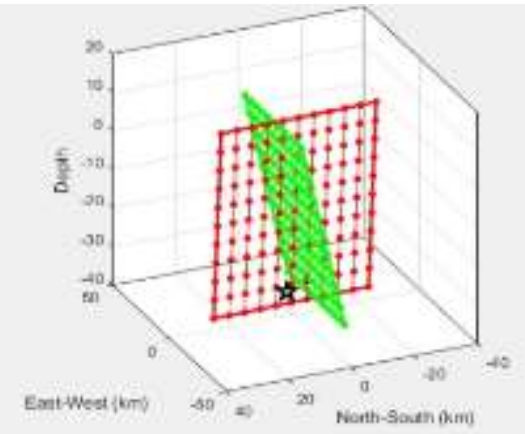

Gambar 11. Output dari program H-C Plot berupa bidang sesar region II

\section{Arah sesar pada region III}

Gempa pada region III dengan lokasi centroid berada pada lintang $-4,95^{\circ} \mathrm{LS}$, bujur $120,17^{\circ} \mathrm{BT}$ dan berada pada kedalaman $10 \mathrm{Km}$. lokasi hiposenter gempabumi yang berada pada lintang $-4,99^{\circ}$ LS dan bujur $120,12^{\circ}$ BT serta berada pada kedalaman $10 \mathrm{Km}$. 


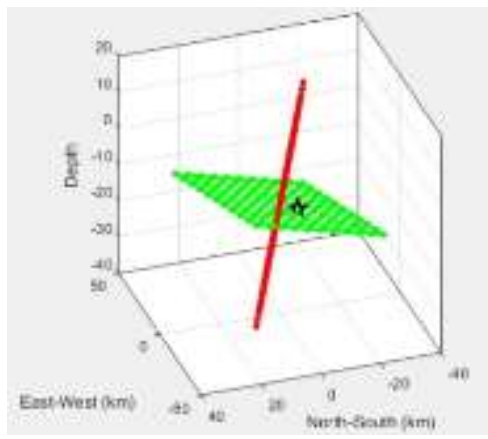

Gambar 12. Output dari program H-C Plot berupa bidang sesar region III

4. Arah sesar pada region IV

Gempa pada region IV dengan lokasi centroid berada pada lintang $-5,58^{\circ} \mathrm{LS}$, bujur $120,12^{\circ} \mathrm{BT}$ dan berada pada kedalaman $16 \mathrm{Km}$. lokasi hiposenter gempabumi yang berada pada lintang $-5,60^{\circ}$ LS dan bujur $120,22^{\circ}$ BT serta berada pada kedalaman $10 \mathrm{Km}$.

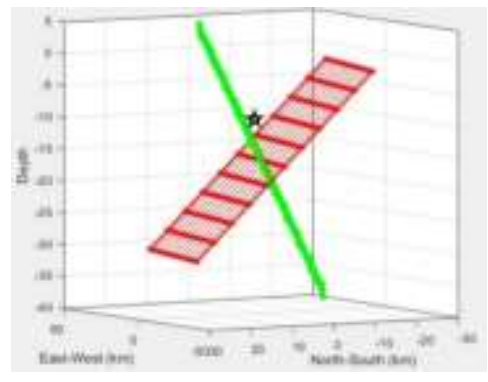

Gambar 13. Output dari program H-C Plot berupa bidang sesar region IV

\section{Arah sesar pada region $\mathrm{V}$}

Gempa pada region $\mathrm{V}$ dengan lokasi centroid berada pada lintang $-6,28^{\circ} \mathrm{LS}$, bujur $120,68^{\circ} \mathrm{BT}$ dan berada pada kedalaman $27 \mathrm{Km}$. lokasi hiposenter gempabumi yang berada pada lintang $-6,28^{\circ}$ LS dan bujur $120,68^{\circ}$ BT serta berada pada kedalaman $27 \mathrm{Km}$.

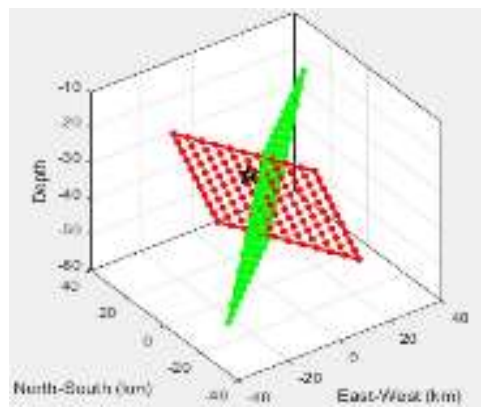

Gambar 14. Output dari program H-C Plot berupa bidang sesar region V. 


\section{KESIMPULAN}

Berdasarkan hasil penelitian ini maka dapat disimpulkan bahwa bidang sesar aktif untuk region I dengan jenis sesar turun (normal fault) berarah N6E/32 SelatanUtara, region II dengan jenis sesar geser (strike slip) berarah N358E/83 UtaraSelatan, region III dengan jenis sesar oblique (oblique fault) berarah N74E/16 Barat Daya-Timur Laut, region IV dengan jenis sesar turun (normal fault) berarah N109E/56 Barat Laut- Tenggara dan pada region V dengan jenis sesar geser (strike slip) berarah N332E/50 Tenggara-Barat Laut.

\section{DAFTAR PUSTAKA}

Abdullah, C.I., Sapiie, B., Magetsari, N. A., Harsolumakso, A. H. 2006. Geologi Fisik. Institut Teknologi Bandung. Bandung.

Afnimar.2009.Seimologi.Istitut Teknologi Bandumg:Bandung.

Al-Syeikh, Dr. Abdullah.2004. Tafsir Ibnu Katsir.Pustaka Imam Syafi'i:Bogor

Amstrong F.2012.Struktur Geologi Sulawesi.Perpustakaan Sains dan Teknologi:ITB

Anderson, E. M.1951. The Dynamics of Faulting.Oliver \& Boys, Edinburgh.

BMKG.2015.Bulletin Gempabumi dan Tsunami Indonesia.Jakarta

BMKG.2017.Skala MMI (Modifier Mercalli Intensity).www.bmkg.go.id

Cronin, Vince. 2010.A Draft Primer on Focal Mecanism Solutions for Geologists.UK.Baylor Universitty

Darma dan Sidi.2000. An outline of the geology of Indonesia. Jakarta: Ikatan Akhli Geologi Indonesia

Elnashai, Amr and Di Sarno, Luigi. 2008. Fundamentals of Earthquake Engineering. West Sussex. Wiley \& Sons, Ltd

Erviawan.2010. lipatan.Makassar.UIN Makassar.

Hall, R., Wilson, M. E. J. 2000. Neogene Sutures in Eastern Indonesia. Journal of Asian Earth Sciences, 18, 781-808

Hamilton, W. 1979. Tectonics of the Indonesian Region. Washington: Geological Survey Profesional Paper 1078. 345p.

Hamka, Prof. Dr.1975. Tafsir Al-Azhar Juzu 20.Sukabumi

Https://agnasgeopraph.wordpress.com/2012/04/20/struktur-geologi/

Https://www.slideshare.net/mobile/army014/materi-kuliah-geologi-sruktur/ 
Kaharuddin.2011.Pengembangan tektonik dan implikasinya terhadap potensi gempa dan tsunami di kawasan pulau Sulawesi. Jurnal

Kementrian Angama RI.2014.Qur'an Hafalan.Halim:Surabaya

Kurniati, Atika.2017.Aplikasi Mekanisme Fokus Dalam Identifikasi Sesar Di Sulawesi Bagian selatan.Unhas:Makassar

Madlazin.2011.Estimasi CMT, bidang sesar dan durasi rupture gempabumi disumatra serta kemungkinan penerapan untuk peringatan dini tsunami (Disertasi). Fisika ITS

Madlazin.2017.Pengaruh Hiposenter Terhadap Ketelitian Penentuan Bidang Sesar Teraktif Menggunakan Metode HC-plot diWilayah Papua. Jurnal Inovasi Fisika Indonesia (IFI) Volume 06 Nomor 03 Tahun 2017, hal 18- 24

Massinai, M.F.I. 2013. Analisis Pola Sebaran Gempa Tektonik Berdasarkan Mekanisme Fokus (Studi Kasus Pulau Sulawesi, Tahun 1993-2012). Skipsi. Universitas Hasanuddin. Makassar

Massinai, Muhammad Altin, Sudraat, Adjat, Lantu.2013. The Influence of Seismik Aktivity in South Sulawesi Area to the Geomorfology of Jeneberang Watershed, Journal of Engineering and Teknolog, Vol 3, No. 10, P.945-948

Noor, Djauhari. 2010. Pengantar Geologi.Program Studi Teknik Geologi Fakultas Teknik:Universitas Pakuan

Okal, E.A.2011.Earthquake, Fokal Mekanism. Springer Science Business Media B. V.Evanston, II. 60208, USA

Santoso, Djoko.2002.Pengantar Teknik Geofisika. Penerbit ITB: Bandung.

Shihab, M. Quraish.2002. Tafsir Al-Misbah.Jakarta:Lentera Hati

Sompotan, Armstrong F.2012.Struktur Geologi Sulawesi.Perpustakaan Sains Kebumian Institut Teknologi Bandung:Bandung.

Sunarjo, Gunawan, M.Taufik, Pribadi, Sugeng.2012.Gempabumi Indonesia Edisi Populer. Badan Metereologi Klimatologi dan Geofisika. Jakarta.

Suyono and Kusnama, 2010, Stratigraphy and Tectonics of the Sengkang Basin, South Sulawesi, Jurnal Geologi Indonesia. 